\title{
Hubungan Status Gizi dan Level Aktivitas Fisik dengan Tingkat Kebugaran pada Pemain Bola Basket di UKM Basket
}

\section{Correlation Between Nutrition Status, Physical Activity and Fitness Level among Basketball Players in Student's Basketball Club}

\author{
Febry Dian Permatasari*1, Annis Catur $\mathrm{Adi}^{2}$, Ratna Candra Dewi ${ }^{3}$
}

\begin{abstract}
ABSTRAK
Latar Belakang: Olahraga bola basket menuntut ketahanan fisik, kecepatan, dan pengeluaran energi yang besar. Pada mahasiswa, sering muncul masalah rendahnya tingkat kebugaran karena aktivitas fisik yang kurang sehingga dapat menghambat kemampuan olahraga. Selain itu, konsumsi makanan dan minuman yang tidak teratur dapat mempengaruhi status gizi. Teknik dan latihan tanpa dilengkapi dengan status gizi baik tidak akan mencapai prestasi yang optimal.

Tujuan: Penelitian ini bertujuan mempelajari hubungan antara status gizi dan aktivitas fisik dengan tingkat kebugaran pemain bola basket di UKM basket Surabaya.

Metode: Penelitian ini menggunakan desain penelitian Cross Sectional. Sampel penelitian sebanyak 40 orang diambil secara acak dengan menggunakan simple random sampling. Pengumpulan data meliputi status gizi dengan pengukuran berat badan dan tinggi badan, kuesioner aktivitas fisik dan pengukuran tingkat kebugaran dengan metode bleep test. Analisis data yang digunakan adalah korelasi Pearson.

Hasil: Mayoritas status gizi responden normal $(85,7 \%)$ laki-laki dan $(84,1 \%)$ perempuan. Mayoritas aktivitas fisik responden adalah tinggi $(52,4 \%)$ laki-laki dan $(73,7 \%)$ perempuan. Sedangkan tingkat kebugaran mayoritas baik dengan (28,5\%) laki-laki dan (26,3\%) perempuan. Adanya hubungan antara aktivitas fisik $(p=0,049)$ dengan tingkat kebugaran, sedangkan status gizi dengan tingkat kebugaran pemain bola basket tidak ditemukan hubungan yang signifikan $(p=0,693)$.

Kesimpulan: Aktivitas fisik berhubungan dengan tingkat kebugaran dan status gizi tidak berhubungan dengan tingkat kebugaran pada pemain bola basket. Pemain bola basket sebaiknya memantau status gizi (IMT) bersamaan dengan melakukan aktivitas fisik seperti olahraga secara rutin dalam kehidupan sehari-hari. Apabila hanya dengan status gizi baik tanpa aktivitas fisik, maka tingkat kebugaran tidak akan meningkat.
\end{abstract}

Kata kunci: aktivitas fisik, bola basket, status gizi, tingkat kebugaran

\section{ABSTRACT}

Background: Basketball is sport that requires physical endurance, speed and high energy expenditure. Some college students have problem like low of fitness level because lack of physical activity, so it can inhibit basketball player's performance. Besides, the irregular consumption of food and drink daily also causes effect nutritional status. Technique and exercise without good nutrition status will not reach optimal achievement.

Objectives: This research aims to analyze of correlation between nutritional status and physical activity with fitness level among basketball players in student's basketball club in Surabaya.

Methods: This was study with cross sectional design. The sample was 40 students who were recruited through simple random sampling. The data collection including nutritional status by measuring the 
weight and height, questionnaire about physical activity and measuring fitness level with bleep test method. Data analysis used was Pearson Correlation.

Results: The majority nutritional status respondents was normal in boys (85.7\%) and in girls (84.1\%). Majority of respondents have high physical activity for both boys (52.4\%) and girls (73.7\%). While the fitness level was mostly good in boys (28.5\%) and girls (26.3\%). There was a significant correlation between physical activity and fitness level among basketball players $(p=0.046)$. However, the correlation between nutrition status and fitness level was not statistically significant ( $p=0.693$ ).

Conclusions: Physical activity was significantly correlated with fitness level and but not with nutrition status. Basketball player should maintain their nutritional status together with physical activity through regular exercise and healthy eating. Normal nutrition status without adequate physical activity will not increase fitness level.

Keywords: basketball, nutrition status, physical activity, fitness level

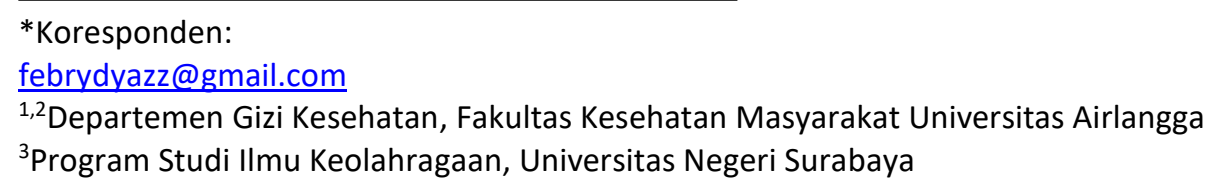

\section{PENDAHULUAN}

Olahraga adalah salah satu bentuk aktivitas fisik yang dilakukan secara terstruktur, terencana dan berkesinambungan dengan mengikuti aturan tertentu dan bertujuan untuk meningkatkan kebugaran jasmani dan prestasi $^{1}$. Menurut Irianto $^{2}$, pengertian kebugaran jasmani adalah kemampuan seseorang melakukan kerja sehari-hari secara efisien tanpa menimbulkan kelelahan yang berlebihan sehingga masih dapat menikmati waktu luangnya. Kebugaran jasmani mempunyai salah satu komponen yaitu daya tahan kardiovaskuler yang dapat diukur dengan VO2 max atau volume oksigen yang dibutuhkan ketika bekerja keras. Semakin banyak tubuh seseorang dapat menggunakan oksigen, semakin banyak pula pekerjaan yang dapat dilakukan. Hal tersebut diperlukan bagi olahragawan agar dapat mencapai penampilan yang maksimal baik saat latihan atau bertanding sehingga dapat meningkatkan prestasi $i^{3}$.

Olahraga bola basket menuntut ketahanan fisik, kecepatan, dan pengeluaran energi yang besar. Untuk mencapai prestasinya, pemain bola basket memerlukan gizi yang cukup, baik kualitas maupun kuantitas ${ }^{2}$. Status Gizi adalah keadaan tubuh sebagai akibat konsumsi makanan dan penggunaan zat-zat gizi, dibedakan antara gizi kurang, baik dan lebih ${ }^{4}$. Keadaan status gizi dan ketersediaan energi dalam jumlah cukup serta pada waktu yang tepat sangat penting dalam dunia olahraga. Teknik dan latihan apabila tidak dilengkapi dengan status gizi baik tidak akan mencapai prestasi yang optimal ${ }^{5}$.

Faktor lain yang mempengaruhi tingkat kebugaran salah satunya adalah aktivitas fisik ${ }^{6}$. Aktivitas fisik adalah aktivitas manusia terbagi menjadi yang tidak dapat terukur dan dapat terukur. Olahraga merupakan kegiatan aktivitas fisik yang terencana dan terukur yang bertujuan untuk kebugaran dan prestasi. Olahraga yang cukup berpengaruh pada tingkat kebugaran individu. Semakin lama dan keras berlatih akan semakin meningkatkan kebutuhan oksigen untuk memenuhi kebutuhan energi ${ }^{7}$.

Berdasarkan penelitian sebelumnya yang dilakukan Mahastuti $\mathrm{dkk}^{8}$ pada pemain bola basket di UKM Basket Universitas Negeri Semarang menyatakan tingkat kebugaran pemain bola basket cukup banyak yang masuk kategori kurang yaitu sebanyak $13 \%$. Sedangkan mayoritas aktivitas fisiknya adalah sedang. Penelitian lain dari Ridlo ${ }^{9}$ yang meneliti pada pemain bola basket di UKM Basket Universitas Islam 45 Bekasi menunjukkan bahwa sebagian besar yaitu sebanyak $47 \%$ pemain bola basket masuk dalam kategori buruk namun dengan status gizi mayoritas baik. Berdasarkan latar belakang tersebut, maka perlu adanya penelitian lebih lanjut tentang hubungan antara status gizi dan 
aktivitas fisik dengan tingkat kebugaran pemain bola basket di UKM Bola Basket.

\section{METODE}

Penelitian ini merupakan jenis penelitian observasional analitik dengan desain studi Cross Sectional. Populasi sebanyak 45 mahasiswa yang tergabung dalam UKM Basket UNAIR dan UNESA. Perhitungan sampel menggunakan rumus uji hipotesis untuk satu proposi populasi dengan ketepatan 95\% dan kekuatan $90 \%$ dan didapatkan sampel sebanyak 40 pemain bola basket. Kriteria inklusi sampel dalam penelitian ini yaitu responden sudah pernah bertanding sebelumnya dan rajin ikut latihan rutin 3 bulan terakhir di UKM Basket UNAIR dan UNESA. Pengambilan sampel dalam penelitian ini menggunakan metode simple random sampling. Variabel dependen penelitian adalah tingkat kebugaran, sedangkan variabel independen yaitu status gizi dan aktivitas fisik.

Karakteristik responden yang dilihat pada penelitian ini diantaranya yaitu jenis kelamin, usia dan uang saku. Pengukuran antropometri berat badan dan tinggi badan untuk mengetahui status gizi responden. Pengukuran berat badan menggunakan timbangan digital (Camry) dengan ketelitian $0,1 \mathrm{~kg}$ dan tinggi badan menggunakan microtoise (GEA) dengan ketelitian $0,1 \mathrm{~cm}$. Hasil pengukuran berat badan dan tinggi badan kemudian dihitung untuk menentukan IMT (Indeks massa tubuh) dan status gizi setiap pemain bola basket. Kategori status gizi berdasarkan Depkes tahun $2004^{10}$ dibagi menjadi 5 kategori yaitu kurus sekali $<17,0$ $\mathrm{kg} / \mathrm{m}^{2}$, kurus $17,0-18,4 \mathrm{~kg} / \mathrm{m}^{2}$, normal $18,5-$ $25 \mathrm{~kg} / \mathrm{m}^{2}$, overweight $25,1-27 \mathrm{~kg} / \mathrm{m}^{2}$ dan obese $>27 \mathrm{~kg} / \mathrm{m}^{2}$. Sedangkan pengukuran aktivitas fisik menggunakan kuesioner dari IPAQ (2005). Kuesioner ini adalah kuesioner Internasional yang dirancang untuk mengukur aktivitas fisik pada orang dewasa dalam kurun waktu seminggu sebelumnya. Skor total nilai aktivitas fisik dilihat dalam METsmenit/minggu berdasarkan penjumlahan dari aktivitas berjalan, aktivitas sedang, dan aktivitas berat dalam durasi (menit) dan frekuensi (hari) yang dikalikan dengan nilai masing-masing METs. Nilai METs untuk ringan aktivitas berjalan adalah 3,3; aktivitas sedang adalah 4,0; dan aktivitas berat adalah 8,0. Setelah ditemukan hasilnya kemudian dikategorikan berdasarkan IPAQ (2005) menjadi tiga kategori yaitu ringan $<600 \mathrm{METs}$ $\mathrm{mnt} / \mathrm{mgg}$, sedang 600-1499 METs mnt/mgg dan berat $>1500$ METs mnt/mgg ${ }^{7}$. Pengukuran kebugaran menggunakan Metode Bleep Test. Bleep test adalah tes dilakukan dengan tes lari bolak-balik dengan jarak 20 meter dengan adanya tingkatan (level) dan balikan (shuttle) ${ }^{11}$. Hasil pengukuran tingkat kebugaran menggunakan Metode Bleep Test dilihat dari berapa tingkatan (level) dan balikan (shuttle) yang dapat ditempuh secara maksimal. Tingkat kebugaran dibagi berdasarkan jenis kelamin dan kategorinya dibagi menjadi 5 tingkatan yaitu kurang sekali, kurang, cukup, baik, dan baik sekali. Jenis kelamin laki-laki dengan kategori kurang sekali $<42 \mathrm{ml} / \mathrm{kg} / \mathrm{mil}$, kurang $42-45 \mathrm{ml} / \mathrm{kg} / \mathrm{mil}$, cukup $46-50 \mathrm{ml} / \mathrm{kg} / \mathrm{mil}$, baik $51-55 \mathrm{ml} / \mathrm{kg} / \mathrm{mil}$ dan baik sekali $>55 \mathrm{ml} / \mathrm{kg} / \mathrm{mil}$. Sedangkan pada jenis kelamin perempuan dengan kategori kurang sekali $<36 \mathrm{ml} / \mathrm{kg} / \mathrm{mil}$, kurang $36-39 \mathrm{ml} / \mathrm{kg} / \mathrm{mil}$, cukup $40-43$ $\mathrm{ml} / \mathrm{kg} / \mathrm{mil}$, baik $44-49 \mathrm{ml} / \mathrm{kg} / \mathrm{mil}$ dan baik sekali $>49 \mathrm{ml} / \mathrm{kg} / \mathrm{mil}^{12}$.

Hasil penelitian dianalisis secara deskriptif dan analitik. Analisis deskriptif yaitu mendeskripsikan semua variabel penelitian (karakteristik atlet, status gizi, aktivitas fisik dan tingkat kebugaran) dalam bentuk tabel distribusi frekuensi. Sajian tabel yang digunakan berdasarkan kategori masingmasing variabel. Analisis analitik menggunakan uji statistik dengan software SPSS versi 16 tahun 2007. Uji statistik yang digunakan untuk hubungan status gizi dan aktivitas fisik dengan tingkat kebugaran adalah Korelasi Pearson karena skala data adalah rasio. Penelitian telah lulus uji etik dari Fakultas Kesehatan Masyarakat Universitas Airlangga No. 283KEPK.

\section{HASIL DAN PEMBAHASAN}

Hasil penelitian karakteristik pemain bola basket dapat dilihat pada tabel 1 . Jenis kelamin pemain bola basket berjumlah $52,5 \%$ laki-laki dan $47,5 \%$ perempuan. Berdasarkan pertumbuhan fisik sejak remaja laki-laki 
cenderung lebih berkembang pada otot atau lean body mass dibandingkan dengan perempuan. Sedangkan pertumbuhan fisik sejak remaja perempuan cenderung lebih berkembang massa lemak tubuh dibandingkan laki-laki ${ }^{13}$. Berdasarkan umur pemain bola basket berusia antara $18-23$ tahun dengan pembagian remaja akhir (18 - 21 tahun) sebanyak 82,5\% dan dewasa awal (22 - 24 tahun) sebanyak 17,5\%. Menurut Susilowati dan Kuspriyato ${ }^{14}$, dewasa awal dimulai sejak seseorang berusia 22 tahun sampai 35 tahun yang ditandai dengan produktivitas tinggi, komitmen hidup, perubahan nilai, penyesuaian dengan cara hidup dan penuh kreativitas. Berdasarkan uang saku per bulan paling banyak pemain bola basket memiliki uang saku sebanyak $>1$ juta per bulan yaitu sebanyak $30 \%$. Uang saku adalah uang yang diberikan oleh orang tua yang digunakan untuk memenuhi kebutuhan mahasiswa selama di tempat kuliah ${ }^{15}$.

Tabel 1. Distribusi Karakteristik Pemain bola basket UKM Basket UNAIR dan UNESA Tahun 2018

\begin{tabular}{lcc}
\hline $\begin{array}{c}\text { Karakteristik } \\
\text { Responden }\end{array}$ & Jumlah & Persen (\%) \\
\hline $\begin{array}{l}\text { Jenis Kelamin } \\
\text { Laki-laki }\end{array}$ & 21 & 52,5 \\
$\quad$ Perempuan & 19 & 47,5 \\
\hline Total & 40 & 100,0 \\
\hline Umur Responden & & \\
$\quad$ Remaja akhir (18-21) & 33 & 82,5 \\
$\quad$ Dewasa awal (22-24) & 7 & 17,5 \\
\hline Total & 40 & 100,0 \\
\hline Uang Saku (Rp) & & \\
$\quad<250.000$ & 7 & 17,5 \\
250.000-499.000 & 8 & 20,0 \\
500.000-749.000 & 5 & 12,5 \\
750.000-1.000.000 & 8 & 20,0 \\
$>1.000 .000$ & 12 & 30,0 \\
\hline Total & 40 & 100,0 \\
\hline
\end{tabular}

Mahasiswa dengan uang saku per bulan yang berkisar <Rp 250.000 dan Rp $250.000-$ 499.000 sebanyak 15 orang atau $37,5 \%$ menggunakan sebagian besar uang saku yang diberikan orang tua tiap bulannya untuk tempat tinggal (kos). Menurut penelitian dari
Aini ${ }^{16}$, besarnya uang saku memberikan pengaruh pada pemilihan jenis makanan yang dikonsumsi.

Tabel 2. Distribusi Status Gizi, Aktivitas Fisik dengan Tingkat Kebugaran Pemain Bola Basket UKM Basket UNAIR dan UNESA Tahun 2018

\begin{tabular}{lcccc}
\hline \multirow{2}{*}{ Variabel } & \multicolumn{2}{c}{ Laki-laki } & \multicolumn{2}{c}{ Perempuan } \\
\cline { 2 - 5 } & $\mathbf{n}$ & $\%$ & $\mathbf{n}$ & $\%$ \\
\hline Status Gizi & & & & \\
Sangat kurus & 0 & 0,0 & 1 & 5,3 \\
Kurus & 0 & 0,0 & 1 & 5,3 \\
Normal & 18 & 85,7 & 16 & 84,1 \\
Overweight & 3 & 14,3 & 1 & 5,3 \\
$\quad$ Obesitas & 0 & 0,0 & 0 & 0,0 \\
\hline Total & 21 & 100,0 & 19 & 100,0 \\
\hline Aktivitas Fisik & & & & \\
Ringan & 4 & 19,0 & 0 & 0,0 \\
Sedang & 6 & 28,6 & 5 & 26,3 \\
$\quad$ Berat & 11 & 52,4 & 14 & 73,7 \\
\hline Total & 21 & 100,0 & 19 & 100,0 \\
\hline Tingkat Kebugaran & & & \\
$\quad$ Kurang sekali & 7 & 33,3 & 0 & 0,0 \\
$\quad$ Kurang & 4 & 19,1 & 1 & 5,3 \\
$\quad$ Cukup & 3 & 14,3 & 6 & 31,6 \\
$\quad$ Baik & 1 & 4,8 & 7 & 36,8 \\
$\quad$ Baik Sekali & 6 & 28,5 & 5 & 26,3 \\
\hline Total & 21 & 100,0 & 19 & 100,0 \\
\hline
\end{tabular}

Pemain bola basket yang mempunyai uang saku cukup banyak cenderung mengonsumsi makanan jajanan yang modern karena biasanya memiliki harga yang lebih mahal. Namun, kekurangan pada penelitian ini adalah kurangnya menggali jumlah uang saku yang digunakan untuk makan sehari-hari.

Tabel 2 menunjukkan hasil penelitian dari status gizi mayoritas pemain bola basket memiliki status gizi normal dengan jumlah $85,7 \%$ laki-laki dan $84,2 \%$ perempuan. Hal ini sesuai dengan penelitian Ridlo $^{9}$ bahwa mayoritas pemain bola basket UKM Basket Universitas Islam Bekasi memiliki status gizi adalah normal. Riwayat status gizi responden yang baik sebaiknya harus terus-menerus diperhatikan karena perubahan berat badan berhubungan dengan kekuatan, kecepatan, ketahanan, ketangkasan dan penampilan. Status gizi yang baik diperlukan untuk mempertahankan derajat kebugaran dan 
kesehatan, serta menunjang pembinaan prestasi olahragawan ${ }^{17}$.

Berdasarkan tabel 2 sebagian besar pemain bola basket tingkat aktivitas fisiknya masuk dalam ketegori berat. Menurut $\mathrm{WHO}^{18}$, pengeluaran energi karena aktivitas fisik adalah hal penting dalam mencapai keseimbangan energi sehingga dapat membantu pemeliharaan berat badan. Aktivitas fisik di luar perkuliahan bagi mahasiswa termasuk aktivitas fisik di waktu luang yang merupakan aktivitas dilakukan pada saat bebas dan dipilih berdasarkan kebutuhan dan ketertarikan masing-masing individu. Hal ini termasuk latihan dan olahraga pada pemain bola basket. Latihan merupakan bagian dari aktivitas fisik yang terencana, terstruktur, berulang dan bertujuan untuk meningkatkan atau menjaga kesegaran jasmani, sedangkan olahraga termasuk sebuah bentuk aktivitas fisik yang melibatkan kompetisi ${ }^{19}$. Latihan rutin pemain bola basket baik dari UKM Basket UNAIR dan UNESA adalah seminggu 3 kali dengan waktu latihan selama 2 jam.

Hasil penelitian tingkat kebugaran menunjukkan pada pemain bola basket laki-laki sebanyak 33,3\% tingkat kebugarannya adalah kurang sekali. Namun, tidak jauh berbeda sebanyak $28,5 \%$ memiliki tingkat kebugaran yang baik sekali. Sedangkan pada pemain bola basket perempuan sebagian besar sebanyak $36,5 \%$ tingkat kebugarannya adalah baik. Secara keseluruhan kebugaran pemain bola basket perempuan lebih baik dari laki-laki. Hasil ini disebabkan karena keterbatasan penelitian yaitu pada pengukuran tingkat kebugaran yang dilakukan pada saat pemain basket selesai latihan sehingga menjadi kurang efektif. Selain itu, penyebab lain adalah kegiatan latihan rutin sempat break untuk sementara waktu pada beberapa saat yang lalu sehingga kegiatan olahraga pemain bola basket menjadi berkurang dan berdampak pada menurunnya tingkat kebugaran.

Hasil ini sesuai dengan penelitian Dewi dan Muliarta ${ }^{20}$ bahwa tingkat kebugaran pada pemain basket SMA di Kota Denpasar mayoritas tingkat kebugarannya baik. Hasil dari tes kebugaran jasmani dapat dijadikan sebagai acuan untuk mengetahui kekuatan dan kelemahan yang dimiliki oleh pemain bola basket, sehingga para pelatih dapat meningkatkan performa permainan para pemain bola basket dan membuat program latihan yang paling tepat dalam mencapai prestasi ${ }^{21}$. Menurut Wiarto ${ }^{3}$, tingkat kebugaran seseorang dapat menentukan kemampuan fisik dalam melaksanakan tugas sehari-hari.

Berdasarkan hasil tabulasi silang antara status gizi dengan tingkat kebugaran (tabel 3), pemain bola basket dengan status gizi normal paling banyak memiliki tingkat kebugaran cukup dan baik dengan jumlah masing-masing sebesar $23,5 \%$ pemain bola basket. Berdasarkan uji korelasi Pearson didapatkan hasil $p=0,693$ menunjukkan tidak ada hubungan signifikan antara status gizi dengan tingkat kebugaran. Hasil ini sesuai dengan penelitian Ramadhana $\mathrm{dkk}^{22}$ yang menunjukkan tidak ada hubungan signifikan antara status gizi dengan tingkat kebugaran. Penelitian ini membuktikan ternyata konstribusi status gizi dengan tingkat kebugaran pemain basket UKM Basket UNAIR dan UNESA tidak terlihat nyata.

Hal ini disebabkan karena jumlah sampel penelitian yang sedikit sehingga penelitian ini kurang menggambarkan hubungan antara status gizi dengan tingkat kebugaran. Selain itu adanya keterbatasan penelitian yaitu waktu pengukuran berat badan dan tinggi badan pada pemain bola basket dilakukan setelah selesai latihan yaitu pada sore dan malam hari. Waktu yang baik untuk pengukuran berat badan dan tinggi badan sebaiknya dilakukan pada pagi hari karena pada pagi hari cenderung perut masih kosong dan belum melakukan aktivitas fisik yang berat ${ }^{23}$.

Secara teori, status gizi yang baik cenderung tingkat kebugarannya baik pula, karena apabila status gizi baik maka energi dalam tubuh cukup sehingga dapat beraktivitas dengan baik. Kegiatan fisik memberikan pengaruh besar pada tingkat kebugaran. Setiap kenaikan IMT sebesar $1 \mathrm{~kg} / \mathrm{m}^{2}$ di ikuti dengan penurunan VO2max sebesar 1,30 $\mathrm{ml} / \mathrm{kgBB} / \mathrm{menit}^{24}$. Tingkat kebugaran sendiri dipengaruhi oleh beberapa faktor yaitu faktor internal dan eksternal. Faktor internal adalah umur, jenis kelamin dan genetik. Sedangkan faktor eksternal adalah status gizi, status kesehatan, aktivitas fisik, kebiasaan olahraga dan kebiasaan merokok. Kegiatan fisik 
Tabel 3. Tabulasi Silang Status Gizi dan Aktivitas Fisik dengan Tingkat Kebugaran Pemain Bola Basket UKM Basket UNAIR dan UNESA Tahun 2018

\begin{tabular}{|c|c|c|c|c|c|c|c|c|c|c|c|c|c|}
\hline \multirow{3}{*}{ Variabel } & \multicolumn{10}{|c|}{ Tingkat Kebugaran } & \multirow{2}{*}{\multicolumn{2}{|c|}{ Total }} & \multirow{3}{*}{ p } \\
\hline & \multicolumn{2}{|c|}{$\begin{array}{l}\text { Kurang } \\
\text { sekali }\end{array}$} & \multicolumn{2}{|c|}{ Kurang } & \multicolumn{2}{|c|}{ Cukup } & \multicolumn{2}{|c|}{ Baik } & \multicolumn{2}{|c|}{ Baik sekali } & & & \\
\hline & $n$ & $\%$ & $\mathrm{n}$ & $\%$ & $\mathbf{n}$ & $\%$ & $\mathbf{n}$ & $\%$ & $\mathrm{n}$ & $\%$ & $\mathbf{n}$ & $\%$ & \\
\hline \multicolumn{14}{|l|}{ Status Gizi } \\
\hline Sangat Kurus & 0 & 0,0 & 0 & 0,0 & 0 & 0,0 & 0 & 0,0 & 1 & 100,0 & 1 & 100,0 & \multirow{6}{*}{0,693} \\
\hline Kurus & 0 & 0,0 & 0 & 0,0 & 0 & 0,0 & 0 & 0,0 & 1 & 100,0 & 1 & 100,0 & \\
\hline Normal & 6 & 17,6 & 5 & 14,7 & 8 & 23,5 & 8 & 23,5 & 7 & 20,6 & 34 & 100,0 & \\
\hline Overweight & 1 & 25,0 & 0 & 0,0 & 1 & 25,0 & 0 & 0,0 & 2 & 50,0 & 4 & 100,0 & \\
\hline Obesitas & 0 & 0,0 & 0 & 0,0 & 0 & 0,0 & 0 & 0,0 & 0 & 0,0 & 0 & 0,0 & \\
\hline Total & 7 & 17,5 & 5 & 12,5 & 9 & 22,5 & 8 & 20,0 & 11 & 27,5 & 40 & 100,0 & \\
\hline \multicolumn{14}{|l|}{ Aktivitas Fisik } \\
\hline Ringan & 1 & 22,3 & 0 & 0,0 & 1 & 33,3 & 0 & 0,0 & 1 & 33,3 & 3 & 100,0 & 0,046 \\
\hline Sedang & 1 & 28,6 & 2 & 28,6 & 1 & 14,3 & 0 & 0,0 & 2 & 28,6 & 7 & 100,0 & \\
\hline Berat & 2 & 6,7 & 3 & 10,0 & 9 & 30,0 & 10 & 33,3 & 6 & 20,0 & 30 & 100,0 & \\
\hline Total & 7 & 17,5 & 5 & 12,5 & 11 & 22,5 & 10 & 25,0 & 9 & 22,5 & 40 & 100,0 & \\
\hline
\end{tabular}

memberikan pengaruh besar pada tingkat kebugaran. Maka dari itu, apabila kegiatan fisik seperti latihan fisik tidak dilakukan teratur dan terus-menerus maka tingkat kebugaran juga bisa menjadi kurang baik. Sehingga, meskipun seorang pemain bola basket memiliki status gizi baik namun kegiatan fisiknya kurang maka belum tentu tingkat kebugarannya akan baik pula ${ }^{6}$.

Berdasarkan tabel 3 menunjukkan hasil tabulasi silang antara aktivitas fisik dengan tingkat kebugaran. Hasil uji korelasi Pearson menunjukkan adanya hubungan signifikan antara tingkat kebugaran dan aktivitas fisik responden $(p=0,046)$. Hasil ini sesuai dengan penelitian Vania $\mathrm{dkk}^{17}$ bahwa terdapat hubungan signifikan antara aktivitas fisik dengan tingkat kebugaran pada atlet softball. Menurut Sharkey ${ }^{6}$, aktivitas fisik lebih nyata memberikan dampak yang baik untuk kesehatan daripada tingkat kebugaran individu. Namun, aktivitas yang cukup dapat menghasilkan kebugaran diatas rata-rata dan membuat tubuh lebih sehat. Aktivitas fisik seperti latihan fisik rutin dilakukan dapat mencapai potensi yang diinginkan. Melakukan aktivitas fisik secara rutin dapat meningkatkan efisiensi kardiovaskular dengan mengurangi denyut jantung baik pada saat istirahat atupun pada saat beban kerja maksimal. Melakukan aktivitas fisik dapat memantapkan efisiensi pernapasan dengan pengambilan napas yang lebih lambat sehingga lebih banyak oksigen yang mencapai paru-paru sehingga tingkat kebugaran dapat meningkat ${ }^{25}$.

\section{KESIMPULAN}

Aktivitas fisik berhubungan dengan tingkat kebugaran pada pemain bola basket. Para pemain bola basket mengikuti kegiatan latihan rutin yang dilaksanakan 3 kali dalam seminggu, hal ini menunjukkan bahwa aktivitas fisik pemain bola basket cukup tinggi. Melakukan aktivitas fisik secara rutin dapat meningkatkan efisiensi kardiovaskular dengan mengurangi denyut jantung baik pada saat istirahat atupun pada saat beban kerja maksimal. Berbeda dengan status gizi yang tidak berhubungan dengan tingkat kebugaran. Hal ini disebabkan karena jumlah sampel penelitian yang sedikit sehingga penelitian ini kurang menggambarkan hubungan antara status gizi dengan tingkat kebugaran. Selain itu adanya keterbatasan penelitian yaitu waktu pengukuran berat badan dan tinggi badan pada pemain bola basket dilakukan setelah selesai latihan yaitu pada sore dan malam hari. Pemain bola basket sebaiknya memantau status gizi (IMT) bersamaan dengan melakukan aktivitas fisik seperti olahraga secara rutin dalam kehidupan sehari-hari. Apabila hanya dengan 
status gizi baik tanpa aktivitas fisik, maka tingkat kebugaran tidak akan meningkat.

\section{ACKNOWLEDGEMENT}

Penulis mengucapkan terima kasih kepada pemain bola basket dari UKM Bola Basket UNAIR dan UNESA yang sudah bersedia menjadi responden dan meluangkan waktu dalam penelitian ini. Selain itu, penulis juga berterima kasih kepada masing-masing pelatih yang sudah membantu untuk memimpin jalannya bleep test yang digunakan untuk mengukur tingkat kebugaran.

\section{REFERENSI}

1. Kemenkes. Pedoman Gizi Olah Raga Prestasi. (Kemenkes RI, 2014).

2. Irianto, D. P. Panduan Gizi Lengkap Keluarga dan Olahragawan. (Andi Offset, 2006).

3. Wiarto, G. Panduan Berolahraga untuk Kesehatan dan Kebugaran. (Graha IImu, 2015).

4. Almatsier, S. Prinsip Dasar Ilmu Gizi. (Gramedia, 2001).

5. Hidayati, N. L. Asuhan Gizi Olahraga. (Rapha Publising, 2015).

6. Sharkey, B. . Kebugaran dan Kesehatan. (RajaGrafindo Persada, 2003).

7. Gibney, M. J., Margetts, B. M., Kearney, J. M. \& Lenore, A. Gizi Kesehatan Masyarakat. (Penerbit Buku EGC, 2005).

8. Mahastuti, F., Rahfliudin, Z. \& Suroto. Hubungan Tingkat Kecukupan Gizi, Aktivitas Fisik dan Kadar Hemoglobin dengan Kebugaran Jasmani (Studi pada Atlet Basket di Universitas Negeri Semarang). J. Kesehat. Masy. 6, 458-466 (2018).

9. Ridlo, A. F. Profil Status Gizi dan Kapasitas V02 Maksimal Pada Mahasiswa UKM Basket di Universitas Islam " 45 " Bekasi. Semin. Nas. "Peningkatan Kualitas Penulisan Karya Ilmiah" Stok Bina Guna 1-8 (2017).

10. Soetarjo, S. \& Soekatri, M. Gizi Seimbang dalam Daur Kehidupan. (Gramedia Pustaka Utama, 2011).

11. Mackenzie, B. Beep VO2 max Test. (2001). Available https://www.brianmac.co.uk/beeptest. htm.

12. Heywood, V. Advanced Fitness Assessment and Exercise Prescription. (Human Kinetics, 2006).

13. Fikawati, S., Syafiq, A. \& Veratamala, A. Gizi Anak dan Remaja. (RajaGrafindo Persada, 2017).

14. Susilowati \& Kuspriyanto. Gizi dalam Daur Kehidupan. (Refika Aditama, 2016).

15. Wahid, M., Kurniawan, W. \& Widyaningsih, T. D. Hubungan Pola Konsumsi Pangan dan Besar Uang Saku Mahasiswa Manajemen Bisnis Dengan Mahasiwa Jurusan Teknologi Hasil Pertanian Universitas Brawijaya Terhadap Status Gizi. J. Pangan dan Agroindustri 5, 1-12 (2017).

16. Aini, S. N. Faktor Risiko Yang Berhubungan Dengan Kejadian Gizi Lebih Pada Remaja Di Perkotaan. Unnes J. Public Health. 2, 2-5 (2013).

17. Vania, E. R., Pradigdo, S. F. \& Nugraheni, S. Hubungan Gaya Hidup, Status Gizi Dan Aktivitas Fisik Dengan Tingkat Kesegaran Jasmani (Studi Pada Atlet Softballperguruan Tinggi di Semarang Tahun 2017). J. Kesehat. Masy. 6, 449457 (2018).

18. Who, W. H. O. Global recommendations on physical activity for health. Geneva World Heal. Organ. 60 (2010). doi:10.1080/11026480410034349

19. Sudiana, I. K. Peran Kebugaran Jasmani bagi Tubuh. Semin. Nas. FMIPA UNDIKSHA IV 389-398 (2014).

20. Dewi, A. A. F. \& Muliarta, I. M. Daya Tahan Kardiorespirasi Siswa Pemain Basket Sekolah Menengah Atas Di Kota Denpasar Lebih Baik Dari Pada Siswa Bukan Pemain Basket. 5, 1-7 (2016).

21. Zulfiyani, L. \& Indra, N. E. Persepsi Atlet Terhadap Tingkat Kelelahan Pada Multistage Fitness Test Dan Yo-Yo Intermittend Recovery Test Di Timbasket Putra Sma Negeri 4 Yogyakarta. Program Studi Ilmu Olahraga, Fakultas IImu Keolahragawan. Medikora XVI, 1-13 (2015).

22. Ramadhana, M. M. L. \& Prihanto, J. B. Hubungan Antara Status Gizi Dengan Tingkat Kebugaran Jasmani Siswa Di Sma 
Negeri Plandaan Jombang. J. Pendidik. Olahraga dan Kesehat. 4, 467-471 (2016).

23. Pacanowski, C. R. \& Levitsky, D. A. Frequent self-weighing and visual feedback for weight loss in overweight adults. J. Obes. 2015, 1-9 (2015).

24. Budiarto, R. A. Hubungan Antara Indeks Massa Tubuh dan Nilai Volume Oksigen
Maksimal (VO2 maks) Pada Mahasiswa Apikes Citra Medika Surakarta. (Universitas Muhammadiyah Surakarta, 2012).

25. Widhiarta, F. Dengan Nilai Estimasi VO2 Max Pada Siswa Dan Siswi Smp. (Universitas Indonesia, 2013). 